\title{
The relationship between democracy and women participation in politics
}

\author{
Zungura Mervis (corresponding author) \\ Dept of Political Science, University of Zimbabwe \\ Box MP 167, Mt Pleasant, Harare, Zimbabwe \\ Tel: $2634303211 \quad$ E-mails: mzungura@yahoo.com \\ Nyemba Eve, Mutasa Florence and Muronza Caroline. \\ Dept of Political Science, University of Zimbabwe \\ Box MP 167, Mt Pleasant, Harare, Zimbabwe \\ Tel: 2634303211 E-mails: zvichaeve@gmail.com \\ fmutasa@yahoo.com,cmuuronza@yahoo.com
}

Received: March 05, 2013 Accepted: March 28, 2013 DOI: 10.5296/jpag.v3i1.3516

\begin{abstract}
This paper analyses the relationship between democracy and women participation in politics. Democracy is supposed to translate into equal power relations between men and women. Evidence on the ground shows little or no connection between democracy and levels of women political participation as those countries regarded as highly democratic have low women representation compared to those regarded as less democratic. This paper attempts to answer the following major questions: is there a relationship between a country's democratic level and the number of women in political positions? At political party levels, does it follow that democratic parties have more women than parties regarded as authoritarian? Are countries wholly committed to increasing women participation in politics to enhance democracy? Or is the signing of agreements aimed at increasing women in political decisions simply rhetoric? Is there a relationship between the wealth a country has and the number of women in political positions? Documentary evidence, in-depth interviews and key informant interviews highlighted that there is no positive rapport between democracy and women involvement in politics as democratic countries and parties have less women than autocracies. Political commitment to increased women participation by all countries is the solution to women involvement in politics. Gender should be preserved as an unequivocal goal of democracy.
\end{abstract}

Keywords: Democracy, autocracy, women, political participation, correlation 


\section{Introduction}

The achievement of female suffrage by most women worldwide has shifted attention in particular to women's political representation, in the sense of their presence within the democratically constituted leadership (Randall 2011:3). Democracy is a political system that has been adopted by most governments worldwide as the best form of government. Democracy means more than just increasing the numbers of women in politics. It means increased women participation in policy making both at the domestic and international level. Documentary evidence and politicians interviewed have evidenced that countries and parties labelled as democratic have fewer women representation in political positions than those labelled as autocratic. The Inter - Parliamentary Union (2008:13) notes that a democratic parliament reflects the views and interests of the society from which it is drawn and allows those perspectives to shape the society's social, political and economic future. Therefore, equal participation means parity in representation between men and women in both numbers and the levels of decision making. It should reflect the views and interests of both men and women in society. Democracy is not democracy until women's voices are amplified in legislation, political institutions and processes. Democracy is not democracy without the inclusion of women in politics. As Madeleine K. Albright ( ) puts it,

"Success without democracy is improbable; democracy without women is impossible".

Although most countries have been ratified agreements aimed at increasing women participation in politics, politics still remains the domain of men. The issues that directly affect the lives of women are predefined as outside the proper realm of politics (Eisenstein, 1984). Georgina Waylen (1994) argues that any analysis that fails to incorporate a gender perspective and ignore the actions and impacts of certain groups will be flawed. Barriers to increased women participation in politics include lack of proper funding, socio economic values and cultural values to mention a few. The following questions directed this research

- Is there a relationship between institutional democracy (both at national and party levels) and the democratization of power between men and women?

- Can women ever achieve substantive representation in political institutions?

- Is there a correlation between the wealth of a country and the number of women in political positions?

- Is increased women political participation a panacea for democratization in the world?

\section{Background}

\subsection{Barriers to Increased Women Participation in Politics}

Women constitute over $50 \%$ of the world population yet they are the most marginalized politically, economically and socially (National Democratic Institute for International Affairs 2010:12). 70\% of people in abject poverty living on less than $\$ 1$ per day in the world are women (IPU 2012:3). This connotes that women represent the largest proportion of the world's poorest. Sociologists have termed this the "feminisation of poverty", Butler, (2004:314). Since women constitute the majority of the world's poor, they do not have the leverage to campaign for office or influence national or foreign policy because of their financial handicap. Even in liberal democracies and industrialised nations men are financially more endowed than women hence they have a competitive advantage over women in politics. Furthermore, women who seek political office are restricted and intimidated by males and society which deprives them the opportunity to participate in politics.

Democracies and autocracies alike have sidelined women to the peripheries of sloganeering and cheer leading denying them access to political office because of the patriarchal tendencies in society to sideline women because of their "unprivileged sex". Other barriers to 
effective women participation are lack of education and confidence, rivalry among women, religion and patriarchy. Ann Linde (2012:1) of the Swedish Social Democratic Party has identified further "hidden barriers" to women's participation, which include making women feel invisible even when they occupy political spaces, making women look ridiculous during parliamentary debates, withholding information from women to display their ignorance, burdening women with guilt and shame for abandoning traditional constructed views about women and finally, the "double burden" they face when they have to choose between family and work.

\subsection{International Conventions on Democratic Women Political Participation}

The United Nations (UN) in Article 7 of the Convention on the Elimination of All Forms of Discrimination against Women (CEDAW) of 1979 provides for democratic representation of women in politics. It stipulates that all countries that are signatories to the convention should...

"...ensure to women, on equal terms with men, the right to vote in all elections and public referenda and to be eligible for election to all publicly elected bodies... and to participate in the formulation of government policy and the implementation thereof and to hold public office and perform all public functions at all levels of government"

Many countries, including Zimbabwe have failed to adhere to the provisions of CEDAW as women political participation has remained marginal. Zimbabwe has not ratified CEDAW which makes the implementation of its provisions nominal if not cosmetic. Further, the United States of America (USA), Bahrain, Palestine, Qatar, Saudi Arabia, Sultanate of Oman, Syrian Arab Republic and the United Arab Emirates (UAE) are among the countries that have not ratified CEDAW (IPU 2012:3). USA is the only liberal democracy and nation that has not ratified CEDAW depicting a gloomy picture about the political will of democracies to empower and increase women in various political institutions. This reiterates the notion that the definition of democracy is gender blind as it refers to equality between people and not between men and women (Azza Karam, 1998).

The UN in an attempt to facilitate the inclusion of women in mainstream politics worldwide reiterated the need to democratize political institutions by drafting resolution (A/RES/66/130) on Women's Political Participation in the 2011 General Assembly, which reaffirms

“... that the active participation of women, on equal terms with men, at all levels of decision-making is essential to the achievement of equality, sustainable development, peace and democracy"

In addition to the above, Security Council resolution 1325 provides for Member States to increase the representation of women at all decision making levels. The major weakness of international conventions and resolutions is that a state can choose to observe the provisions or not to. The 30 percent critical mass mark for women representation in politics has been reached or exceeded in only 28 countries (www.indi.org). International conventions and resolutions are not binding hence they can be violated without effective legal redress. Hence, the democratization of politics to achieve gender parity in politics worldwide remains illusory. The UN through its principal organs, the General Assembly and Security Council have demonstrated that international bodies have the political will to empower women to participate in local politics. The marginalization of women is therefore more apparent at the domestic and not international level. Regional organizations like the African Union and sub-regional organizations like Southern Africa Development Community (SADC) have adopted declarations to ensure member states increase women representation in their political institutions. The African Union adopted the African Protocol on the Rights of Women in Africa (2003), whilst SADC endorsed the Declaration on Gender and Development and its addendum on the Prevention of Violence against Women and Children (1997). The SADC Declaration stipulated that all countries were to ensure;

...the equal representation of women and men in the decision making of member states and 
SADC Structures at all levels and the achievement of at least [a] 30 percent target of women in political decision making structures by the year 2005 .

This target which has been raised to $50 \%$ by both the African Union and regional organizations like SADC in Africa is yet to be met by most countries painting a gloomy picture on the prospects of increased women political participation in Africa.

\section{Literature review and theoretical/conceptual framework}

\subsection{Arguments for Increased Women Participation in Politics}

The debate on democracy and increased women political participation gained prominence first with 'second-wave' feminism from the 1960s and then with 'third wave' democratization from the 1970s (Randall, 2011:2). Samuel Huntington in his discussion on the waves of democracy highlighted that the third wave of democracy which began in the 1970s is currently affecting most third world countries that are now democratizing due to a number of factors among them, their newly found self - determination, the end of the cold war and recently "the Arab spring" (Gates et al 2007:1). After gaining universal suffrage, beginning with New Zealand in 1883 and Kazakhstan in 1994, most women require equal participation in politics that goes beyond voting.

According to (Dahlerup, 1998) women as full citizens constituting at least half the population of the world have the right to proportional representation in politics. From a feminist perspective, especial interest has focused on the claim that women will be more inclined to further 'women's interests' hence women need to address the issues that affect them as men cannot reliably represent women's interests since men and women have contradictory interests on certain issues. For instance, women are more interested in child and health care, environmental issues and other social issues which might not be of interest to men. In support of the feminist perspective www.ndi.org argues that without the full participation of women in decision making processes and debates about policy processes and citizens, issues of greater importance to women will be neglected or the way in which they are addressed will be sub-optimal to women's perspectives.

According to the World Bank (2001), women are less corrupt than men. The world body observed that a strong relationship between relatively high levels of women's political involvement and low levels of corruption existed hence, the argument for more women participants in politics. Women are considered as more peaceful and less violent than men, hence their increased participation in politics will bring a stronger commitment to peace. Since the numbers of women increased in Rwanda's legislature to over 50\% after the 2003 elections, Rwanda has not experienced any political tumults to the scales of the Rwandan genocide of 1994. They are other factors that contributed to the peace process but the fact that women are at the helm of the country's legislature is a significant contributory factor to the maintenance of peace and security in the country.

However, it can be argued that some women leaders such as Golda Meir, Margaret Thatcher, Condoleezza Rice and Hillary Clinton can be hardliner politicians like their male counterparts. For instance, Hillary Clinton was a key player in the Libyan conflict that brought the demise of Muammer al Ghaddafi and Margaret Thatcher instigated the invasion of the Falkland Islands in Argentina during her term as the Prime Minister of Britain in 1981. Other arguments for increased women participation in politics are that when women are empowered as political leaders, countries experience higher standards of living. In Zimbabwe, the Shona saying "musha mukadzi", translated as "a home is a woman", means that without women there can be no homes, families and consequently, nations. In addition, according to the National Democratic Institute for International Affairs (2010:14) women do not necessarily work along hierarchical lines hence they are more likely to work across party lines, even in highly partisan environments. Oppah Muchinguri has attested to the fact that most women visit ZANU PF Women's League, ignorant of the that it is a party organization. She reiterated that she often assists women from all political affiliations because women encounter similar challenges and they need to be united to overcome those challenges. 


\subsection{Descriptive and Substantive Representation}

Women in parliaments constituted 20\% of legislators worldwide in 2012 (Inter Parliamentary Union (2012:1). This percentage depicts low levels of women representation in most parliaments in the world. However, this percentage of women representation in national parliaments in the world is the highest compared to 19.3\% in 2010 (Randall 2011:4), 16\% in 2005 (IPU 2005:1), 11.3 per cent in 1995 (Norris and Krook 2011:6) and 10.9\% in 1975. Earlier years have registered lower percentages depicting that the number of women legislators of 2012 has increased in national parliaments due to the introduction of quotas, constitutional and electoral reforms, changes in party structures and processes, capacity building and parliamentary reform.

Although the statistics above depict an increase in the numbers of women in government worldwide, the participation of women in decision making has been nominal. Pitkin (1967:12) notes that most women legislators are involved in descriptive, or mirror representation with little prospects for substantive representation. Women are clustered in soft portfolios such as social services, education, tourism, culture and housing (webarchive.ssrc.org). In Zimbabwe, women have never occupied powerful policy ministries like home affairs, foreign affairs and defence, but are occupying ministries like women affairs (Minister Olivia Muchena) and small to medium enterprises (Minister Stembiso Nyoni). Consequently, the resultant effect is that women legislators do not influence domestic or international policy and as a result their participation is relative and not effective. If effective participation is to be achieved in national parliaments, there is need for women to exercise substantive representation in which the representative stands for the views or objective interests of those being represented not just representing a certain quota that must be met by the government. However, women still most often than not, add to the numbers in most parliaments but have little or no say on most decisions that are implemented. Hence, while globally, the numbers of women in governments are increasing, the quality of women representation in politics remains dismal.

\subsection{Relationship between levels of wealth and women participation in politics}

Boosting women political participation and decision making around the world is fundamental for democracy and essential for achieving sustainable development (www.ind.org ). There is little correlation between a country's development level and the proportion of women in power (webarchive.ssrc.org). The Bahamas have the greatest GDP per capita but the proportion of women in power is low, and the relationship is again negative in South America (ibid). Rwanda and Mozambique are amongst the poorest countries in the world, but have more women in parliament compared to wealthy countries like the United States. United States has low women representation though it is regarded as one of the wealthy countries. The higher a country's GDP per capita in the Caribbean, the lower the proportion of female cabinet ministers (webarchive.ssrc.org). Standards of wealth do not include women participation hence no direct relationship exists between wealth and levels of women participation. According to Mc Donough $(2002$, 535) the transition to democracy in the United States decreased the political citizenship of women because some women lost the right to be queens and no women gained right to vote. As scnu.edu.cn notes the analysis of democracy and gender inequality show a strong relationship with strong recruitment but a negative relationship with other aspects of democracy such as women representation. Paxton 2004 cited by scnu.edu.cn finds out democracy to be either insignificantly or negatively related to women representation.

\section{Research findings}

\subsection{The Correlation between Political Systems and Women Participation in Politics}

\subsubsection{Autocracies vs. Democracies}

Rwanda is ranked number 136 on the 2011 democracy index by the Economist Intelligence Unit (EIU) and number 35 in the very high warning category on the 2012 Failed States Index compiled by the Fund for Peace $(2012: 4)$ yet it is ranked $1^{\text {st }}$ in the world by the 
Inter-Parliamentary Union as a country that has the highest percentage of women representation in its parliament worldwide. Although Rwanda is classified as an authoritarian regime on the Democracy Index of 2011, it has 56.30\% women in parliament, a sharp contrast to USA, classified as a very stable democracy by the Fund for Peace in its 2012 Failed states Index (Fund for Peace 2012:5). The USA is also classified as a full democracy by the EIU (2011:4) which according to the IPU's classification on women in national parliaments ranks number 80 with $16.9 \%$ representation in congress and senate. Likewise, the United Kingdom, Australia, Canada, Japan and Germany classified as full democracies have low percentages of women representation in their parliaments indicating that authoritarian regimes top the rankings of countries that are more accommodative towards women participation and representation in national parliaments. This is reflected in the EIU Democracy Index of 2011 which classifies Cuba, Rwanda and Angola as authoritarian regimes, Senegal and Mozambique as hybrid regimes and South Africa as a flawed democracy, registering more than $30 \%$ women representation in their parliaments. However, full democracies like Sweden, Finland, Netherlands, Norway and Denmark are also listed in the top 20 countries in the IPU rankings, suggesting that democratic countries do not necessarily have more women in politics than autocratic regimes. Nonetheless, the fact that Rwanda, an autocratic regime, has the highest number of women in parliament in the world suggests that there is no correlation between democracy and increased women participation in politics. To further illustrate this conception, the USA is a case in point.

The USA, a liberal democracy with all the embodiments of equal rights and participation is still to realize gender parity in politics. Women in USA politics constitute $17 \%$ of Senators, $16.8 \%$ of the House of Representatives, $12 \%$ of State Governors, 23.6\% of State Legislators and $8 \%$ of the Mayors of the 100 largest cities (Lawless and Fox 2012:1). These low statistics of women representation in USA politics, indicate that democratic countries do not necessarily promote increased women participation in politics. To support this contention, the distribution of women heads of state and government along political systems will be illustrated. As of March 2012, out of 193 heads of states and governments in the world, 17 were women (Women in Politics Report (2012). Some of the incumbent women heads of states and governments are Agatha Barbara of Malta, Christina Fernandez de Kirchner of Argentina, Ellen Johnson Sirleaf of Liberia, Joyce Banda of Malawi, Eveline Widmer-Schlumpf of Switzerland and Angela Merkel of Germany.

Of the 17 women Heads of State and Government in 2012, 6 were full democracies according to the EIU of December 2011. The democratic countries were Germany, Iceland, Australia, Denmark and South Korea. The rest of the countries with female heads of states and governments were not democracies. These were Liberia, Bangladesh and Malawi which were classified as hybrid regimes. Jamaica, Thailand, Brazil, Slovakia, Trinidad and Tobago, Lithunia and Argentia were ranked as flawed democracies (EIU December 2011). These statistics indicate that there is no relationship between democracy and increased women participation in politics as most heads of states and governments are either presiding over a flawed democracy, a hybrid regime or an authoritarian regime.

Although the statistics above indicate that no correlation exists between democracy and increased women participation in politics, it is worth noting that Scandinavian countries have the highest percentage of women ministers at 48.4 per cent, followed by the Americas at 21.4 per cent and sub-Saharan Africa at 20.4 per cent (Women in Politics Report, 2012:1). These statistics depict that democracies have more women ministers than autocracies. However, it is important to note that; the percentage representation of women ministers in the America's is low, being a percentage higher than the $20.4 \%$ of sub-Saharan Africa. From the above discussion, it can be argued that most democracies do not promote increased women participation in politics.

\subsection{Political Parties and Women Political Participation}

Political parties are often referred to as the gatekeepers of democracy that can influence the level of women's political participation as members and candidates, thereby directly 
contributing to more representative political processes (Norris and Krook (2011:5). Political parties can either increase or decrease the number of women in their political parties by ensuring equality in voting, introducing quotas and ensuring that politics are free from violence and intimidation (National Democratic Institute for International Affairs 2010:12)

In Zimbabwe, the Zimbabwe African National Union Patriotic Front (ZANU PF) adopted the quota system in 2005 and the Movement for Democratic Change (MDC) has no quotas other than the provision that one-third of its National Council must be women and sufficient women must be co-opted, if necessary, to ensure that this is the case (Sachikonye 2005,36). Jessie Majome, an MDC - T Member of Parliament (MP) for Harare West Constituency and key informant interviewee for this study, highlighted the fact that she had won her seat as a result of MDC seats reserved for women during the 2008 elections. Although political parties are supposed to spearhead increased women political participation, they lack the political will to do so due to power struggles between the major political parties in Zimbabwe. Other factors that hinder women political involvement in Zimbabwe include lack of financial resources to campaign, women are skeptical of participation in politics because of the culture of violence, patriarchy and religion.

ZANU PF has a strong arm of the Women's League, led by Oppah Muchinguri, who has devoted herself to fight for women's rights. An in-depth interview with Oppah revealed that most women in the party had to fight harder than men for a seat in the party. Majome noted that MDC has no wing for women. Even though MDC is regarded as more democratic than ZANU PF, it lags behind in terms of women involvement in its political structures. According to the Inter-parliamentary Union (2012:1), Zimbabwe ranks number 90 in the world in terms of women representation in parliament. $15 \%$ of women are represented in Zimbabwe's the lower house whilst $24 \%$ of women are in the senate (Ibid). Similarly assembly.coe.int observes that the Reformed Political Party (Staatkundig Gereformeerde Partij, SGP) in the Netherlands does not allow women to stand as candidates for elections and until 2006 it did not admit women as party members. Again the Dutch Election Law does not include any requirements as regards the gender composition of the lists or obligations for political parties to allow candidates of both sexes to run (ibid). Party quotas have been applied in Sweden as well as Norway mainly because of their subject political culture, and in addition gender equality is treated as issues of high importance (assembly.coe.int). According to Fiona Mackay, though political parties in the United Kingdom have committed themselves to improving women political representation, the overall improvements were negligible.

\section{Conclusions and Recommendations}

From the above analysis it can be noted that most democratic nations do not promote increased women political participation in politics. It was observed that the countries topping the rankings of the Inter Parliamentary Unions "Women in Parliaments" category were depicted as autocratic regimes. In addition, the number of women Heads of State and Government from autocratic, hybrid and flawed democracies were 11 as compared to 6 full democracies headed by women. Political parties in the United Kingdom (just like parties in Zimbabwe) have lacked commitment to increasing women participation in politics though they must play a major role in enhancing women presence in the political arena. Several constraints like religious barriers, patriarchy, illiteracy, poverty and lack of capacity to influence domestic and foreign policy inhibit women involvement in democratic processes. In conclusion, it is imperative to note that democracy is not synonymous with equal representation of women in political institutions neither does it depict increased participation of women in politics. It certainly has not translated into increased women political participation.

Since there is no relationship between democracy and increased women participation in politics, this paper recommends that to increase women participation in full and flawed democracies, autocracies and hybrid regimes alike need to; 


\section{Macrothink}

Journal of Public Administration and Governance ISSN 2161-7104 2013, Vol. 3, No. 1

- Educate men on the importance of gender balancing in politics, so that they prepare themselves to support the advancement of women in politics.

- Initiate public and private financing of women candidates vying for political office.

- Encourage women to work across party lines to advocate for more women participation at all political levels.

- Conduct capacity building programmes to train women in politics and governance

- Instigate a monitoring and evaluation framework that will assess the level and effectiveness of women participation.

- Encourage political will at the top levels of political parties to co-opt more women in politics

- Increase women's access to positive media coverage and feedback

- Encourage women participation in national parliaments so that they influence national policy

\section{Bibliography}

Books

Dahlerup, Drude (1998). 'Using Quotas to increase Women's Political Representation.' In Karam, Azza (ed). Women in Parliament: Beyond Numbers. Stockholm: The International Institute for Democracy and Electoral Assistance.

Karam, Azza (1998). 'Introduction: Gender and Democracy-why?' In Karam, Azza (ed). Women in Parliament: Beyond Numbers. Stockholm: The International Institute for Democracy and Electoral Assistance.

Noms and Krock (2011) Gender equality in Elected Office. A six step Action Plan, Havard University, st Louis

Journals

Goetz, A M (2007), 'Political Cleaners: Women as the New Anti-Corruption Force?' Development and Change, 38 (1), 87-105.

Mackay Fiona, ( 2004) Gender and Representation in the UK: The State of the" Discipline" BJPIR Vol 6, 99-122

Mc Donough (2002) Political Citizenship and Democracy: The Gender Paradox, A Political Science Review, 96(3) 535.

Pitkin, H F (1967), The Concept of Representation, University of California Press: Berkeley Articles and Papers 


\section{Macrothink}

Journal of Public Administration and Governance ISSN 2161-7104 2013, Vol. 3, No. 1

Dollar, D, Fisman, R and Gatti, R (1999), 'Are Women Really the Fairer Sex? Corruption and Women in Government', Working Paper Series No 4, World Bank Randal, V (2011)

Gender and Democracy, Briefing paper, (IDCR) Institute for democracy and conflict resolution, Briefing Paper (ICDR - BP- 08/11)

World Bank (2001) Engendering Development through Gender Equality in Rights, Resources and Voice, Oxford University Press.

IPU, Taking the lead in Making Parliaments more Gender Attuned $7^{\text {th }}$ meeting of Women speakers of Parliament, New Delhi, 3-4 October 2012

UN Article 7 of the convention on the Elimination of All forms of Discrimination against Women (CEDAW)

(A/RES/66/130) on Women Political Parties in the 2011 General Assembly

Websites

Scnu.edu.cn_accessed 19 february 2013

webarchive.ssrs.org accessed 19 february 2013

www.ass.coe.intt_accessed 19 december 2012

www.idea.int_accessed 11 December 2012

www.ind.org_accessed 20 February 2013

www.ndi.org accessed on 14 february 2013

www.failed states index.org accessed on September 142012

www.e.i.u.com accessed 24 June 2012 